\title{
“The Final Push Against the Eternal Enemy" The Serbian Preparations for the First Balkan War
}

\author{
“Ezeli Düşmana Karşı Son Hamle” Birinci Balkan Savaşı için Sırp \\ Hazırlıkları
}

Danilo SARENAC ${ }^{* *}$

\begin{abstract}
The Ottoman Empire played an important role in the formation of the Serbian nationalism. It was perceived as an archenemy that had to be pushed away from the Balkans. The paper explores the Serbian preparations for the potential conflict with the Ottoman Empire at the end of the XIX century. From 1878 to1912 Serbian state invested huge resources in its military in order to be prepared for exploiting any favorable opportunity for penetrating into the "Serbian historical lands" -Kosovo and Macedonia. Apart from the army, the preparatory work encompassed all the aspects of social life such as education, art or public discourse. Decades of meticulous work brought results in October of 1912 when Serbia's citizens responded in formidable numbers to the mobilization call. However, Serbian war preparations were too focused on defeating the Ottoman troops which was linked with troublesome history of the Serb-Turkish relations during the entire XIX century. Problems of postwar organization of the new territories were hardly tackled in detail. Moreover, the Serbian national project was too narrow for encompassing diverse ethnical and religious communities which lived in the former Ottoman possessions in the Balkans.
\end{abstract}

Keywords: The First Balkan War, war preparation, Serbian nationalism, Medievalism.

Öz

Osmanlı İmparatorluğu, Sırp milliyetçiliğinin oluşumunda önemli bir rol oynamıştır. Osmanlı Devleti Balkanlar'dan uzaklaștırılması gereken bir baș düşman olarak algılanmıștır. Makale, 19.yüzyılın sonunda Sırpların Osmanlı İmparatorluğu ile olası bir çatışma durumu için yaptığı hazırlıkları ele

* Bu makale Marmara BAPKO projesi kapsamında SOS-L-080.715.0354 numaralı L tipi proje desteği ile hazırlanmıştır.

** The author is research fellow at the Institute for Contemporary History in Belgrade. He studied in Belgrade (BA) and at the Central European University in Budapest (MA). PhD thesis defended at the Belgrade University. Fields of interests include social and cultural history of the 1912-1918 conflicts in Southern and Central Europe sarenac.danilo@yahoo.com, Orcid: 0000-0001-8733-7236 
almaktadır. 1878'den1912'ye kadar Sırp devleti, "Sırp tarihi toprakları”na -Kosova ve Makedonya'ya - girmek için elverişli olacak ilk firsatta hazırlıklı olmak amacıyla ordusuna devasa kaynak yatırımı yapmıştır. Ordu dışında bu hazırlık çalışmaları eğitim, sanat ya da kamusal söylem gibi toplumsal yaşamın tüm yönlerini kapsamıştır. Yıllarca süren bu titiz çalışma, Sırbistan vatandaşlarının seferberlik çağrısına müthiş ölçüde karşılık verdikleri 1912 yılının Ekim ayında sonuçlarını vermiştir. Ancak, Sırp savaş hazırlıkları, 19.yüzyıl boyunca Sırp-Türk ilişkilerinin sıkıntılı tarihi ile bağlantılı olarak Osmanlı birliklerini yenmeye fazlasıyla odaklanmıștır. Yeni toprakların savaş sonrası örgütlenme sorunları, ayrıntılı olarak ele alınmamıştır. Dahası, Sırp ulusal projesi, Balkanlar'daki eski Osmanlı topraklarında yaşayan farklı etnik ve dini toplulukları kapsamayacak kadar dardı.

Anahtar kelimeler: Birinci Balkan Savaşı, savaş hazırlığı, Sırp milliyetçiliği, Ortaçağcılık.

\section{Introduction}

"The war was declared to Turkey on the $4^{\text {th }}$ of October 1912. That was one of the most popular wars ever fought in our history. ${ }^{3}$ Few centuries, from the XIV until the XIX, all of our epic times were filled with legacy where the cross fought against the crescent..." (Ćorović [1940]1996: 317). This is how, one of the most famous Serbian historians, Vladimir Ćorović, described in 1940 the first moments of the 1912 war. The war enthusiasm was tackled with more detail by a wellknown Serbian professor and journalist, Milorad Pavlović Krpa: “The day of mobilization was the moment of peoples' joy: on the streets, people who never knew each other hugged or kissed each other, while gymnasium pupils left their schools, heading on foot, to military commands, or even strait towards the frontline, all this in order to become volunteers. It was a general movement; it was not the mobilization of the troops, but the general mobilization of the Serbian spirit" (Pavlović 1991: 33).

These descriptions are all too similar to the ones seen in 1914, in Western Europe (Verhey 2006). As these were recently re-questioned and dismissed as only partially correct, it is possible, that the authors mentioned above, idealized the atmosphere in Belgrade in the awakening of the war. However, it is without a doubt that many saw the declaration of the war to the Ottoman Empire as a righteous and necessary step. The situation was very different in July of 1914 when the AustroHungary declared war to Serbia. No signs of enthusiasm were seen then, but a firm resolution to confront the present difficulties.

Both empires were very much detested in Serbia, but why was the reaction in the Serbian public so different in 1914 in comparison to 1912? The poor shape of the "Sick man of Europe" and thus greater chances of winning the war provide only part of the answer. Since gaining independence from the Ottoman Empire in 1878, the Serbian leadership was systematically preparing the armed forces as well as the general public for the next war with "the Turks". ${ }^{4}$ It was supposed to be the crucial step in fulfilling the Serbian national program -the national liberation and unification of all Serbs. Hence, this long preparatory work made the First Balkan War a quite distinct experience

3 Vladimir Ćorović used the Julian calendar in his book, so Serbia delared war tot he Ottoman Empire on the on the 17 th of October by Gregorian calendar.

4 In the sources the contemporaries mostly referred to the Ottoman Empire by using the term “Turkey" or “Turks". 
in comparison to numerous other wars Serbia fought in the XIX and especially XX century. Such thorough preparations for "tomorrow's war" left plenty of material for understanding how the Serbian society perceived the Ottoman Empire as well as its own role in the Balkans and wider, in Europe.

The national unification project was high in the agenda, but the longings of the Serbian elite encompassed also a strong desire to "catch up", in cultural and technological terms, with modern European states. Moreover, the ambition was to be accepted and recognized as a young state, but an old European nation. Traditions of the Serbian medieval state played here an immense role as these were perceived not only as authentic foundations of the modern statehood, but also as a proof of genuine European identity. Moreover, this was the source of legitimacy in advocating future territorial gains.

It is clear that the Ottoman Empire had a defining role in the formation of the Serbian nationalism. It was perceived as an archenemy who was not only to be blamed for the destruction of the Serbian feudal society, but who also presented an obstacle for the realization of the Serbian contemporary project - the one which places all Serbs in one state.

\section{National Goals after the Congress of Berlin (I878-19 I 2)}

From the start the process of building the modern Serbian state was composed of smaller or bigger triumphs won against the Ottoman Empire. Thus, the animosity towards the Ottomans was one of the hallmarks of the Serbian society in the XIX. century. The leader of the First Serbian uprising in 1804, Karadjordje Petrović, earned the place of a founding father of the Serbian state. He made "a radical and fundamental breakaway from the Ottoman Empire" (Stojančević 2004: 272). He was perceived as the one who revived the old, medieval, statehood. His mutiny was eventually crushed in 1813, but one of his commanders, Miloš Obrenović, initiated a new, shortlived rebellion in 1815. Eventually, in 1830 the autonomous Serbian Principality was founded with the occasion of the triumphs during the two mentioned uprisings. Namely, the $8^{\text {th }}$ article of the Bucharest treaty (1812), signed between the Russian and the Ottoman Empire, guaranteed Serbian autonomy and was thus brought back to life in 1830 (Novaković [1904] 2004: 258 ). Despite its limited scope, the self-rule was sufficient for the continuation of the systematic work on developing Serbian national identity.

The anti-Ottoman or better anti-Turk feelings presented a constant feature of the life in the Principality of Serbia as the Ottoman garrisons were still stationed across Serbia. In 1862 an argument about the utilization who had the right to use the local fountain escalated into a major clash between Serbian civilians and Ottoman soldiers. As a result, in 1867, the Ottoman forces retreated from all fortresses in Serbia. The Ottoman flag remained only on top of the Belgrade's fortress, as the reminder that Serbia was still under the Ottoman sovereignty. Dreams of Ottoman Empire's dissolution were omnipresent in the Serbian public. A good example for this kind of thinking was the document written by the Serbian politician Ilija Garašanin who was the adviser 
of Serbian Prince Mihailo Obrenović. The document entitled Načertanije (The Draft) was made in 1844. A tight collaboration of the South Slaves was proposed as a way of fighting against the Ottomans in it. The ultimate aim was to create the joint South Slavic state (Pavlović 2004: 86, 123-124.)

The open hostilities were seen again in 1876 when Serbia joined Montenegro in fighting the Ottoman Empire. The war lasted until 1877 and was ended with the Serbian defeat. A new clash ensued, this time with Russian assistance. The ending was victorious this time and the Serbian troops managed to penetrate to Kosovo in January of 1878. These wars showed the rising importance of public opinion in Serbia. Namely, what preceded the war of 1876 was the rebellion of the Bosnian Serbs against their Ottoman landlords. Demonstrations in Belgrade put pressure on the government to enter the war in order to help its compatriots in the Ottoman Empire. The lists of volunteers were made spontaneously on the streets. The government finally gave way regardless of the fact that no serious preparations were made (Skoko, Opačić 1974: 31-33).

At the Congress of Berlin 1878 Serbia gained independence and its territory was expanded for four more districts. In 1882, with the help of Vienna, Serbia was elevated to the rank of kingdom. King Milan Obrenović thus became the first Serbian ruler crowned since the middle ages. Coupled with the state independence, this was a huge national success. However, the national ideals were far from being fulfilled. Famous Serbian jurist Slobodan Jovanović wrote that "Serbian nationalism looked like fanaticism of one prosecuted sect" (Anić, 1993: 137). Namely, placing all Serbs in one umbrella state became dominant idea in the country. Here, the Italian model of national unification resonated strongly as this was the most recent example of such practice in Europe. ${ }^{5}$

Serbian nationalism had a genuine popular character (Hutchinson, Smith 1994: 177). Peasant masses entered politics in 1880s. Namely, the People's Radical Party was the most popular political organization as it relayed on free farmers who made up to $90 \%$ of the country's population at the turn of the century. The party advocated self rule on municipal level as well as greater power of the National Assembly. In foreign politics, it fought for the unification of all Serbs and cordial relations with Russia. Leon Trotsky, who travelled thru Serbia and Bulgaria for several times due to his journalism profession, saw the two countries as "belated states" (Šemjakin 116.). He wrote that western cultural models were only imitated in these countries, while traditionalism still remained omnipresent in the everyday life. Indeed, in many aspects Serbia was typical new Balkan Christian state where authoritarianism and liberalism went hand in hand (Pavlović 2004: $111)$.

The fact that numerous Serbs lived within the boundaries of the two empires did not make national program less ambitious. The clash with Vienna was seen by many as something inevitable, but what will take place in distant future. However, the relations with the Ottoman Empire were seen as much more critical. Namely, as the power of central administration in Istanbul weakened,

5 For more recent study of Serbian nationalism see: Srbi 1903-1914 istorija ideja, edited by Miloš Ković, Clio: Belgrade 2015. 
the Serbian population was exposed to greater violence. Consequently, the alarming news were arriving to Belgrade on daily bases. At the same time Serbian migrants from Kosovo or Sandzak Novi Pazar were arriving to the Kingdom of Serbia. Moreover, fears grew in Serbia that Great Powers might resolve the issue of Turkey in Europe on their own, without taking into consideration the interests and desires of the Balkan states. The Austro-Hungarian occupation of Bosnia and Herzegovina of 1878 only increased such fears. Namely, these areas were erroneously seen from Belgrade as "pure Serbian lands" as the rights of local Bosnian Muslims and Croats were not taken into consideration. Thus, losing Bosnia and Herzegovina in 1878 and definitely in 1908 was understood in Belgrade as the ultimate injustice.

The Serbian elite became obsessed with the idea that it must be better prepared for the next turbulence in the Balkans. It was clear that the subsequent crisis will probably occur in the Ottoman Empire. The fact that no one knew when and how this might cause provoked anxiety and fear. Will the Serbian society be ready to cope with sudden challenge or it will be a passive spectator? The war with the Ottoman Empire was more or less seen as a sure thing in this context. In 1903, on the occasion of the $25^{\text {th }}$ anniversary of the Serb-Turkish war and the liberation of the southern Serbian town of Niš, king Alexandar Obrenović (1888-1903) said: "Let the whole world know, that no one can take a single foot of land in the Balkans without giving Serbia its own share". Russian deputy in Serbia wrote in March of 1903 that the dearest thought of the king would be to march into Macedonia (Rajić, 2014: 387). The Great Powers criticized the king who was accused of being a destabilizing factor in the Balkans as he was disturbing the current status quo (Rajić, 2014: 379). In public the ideas of war with the Turkey appeared regularly, but only in disguised, even ciphered manner. "Great tasks ahead", "sacred national mission", "big things waiting at our doorstep" - were all the phrases which could be heard in the National Assembly or found in books and papers (Milenković, 1991: 436).

\section{National Ambitions and the Medieval Legacy}

In creation of the modern Serbian state and formulation of its national goals, the medieval legacy played an immense role. It was essential in building national identity, but was also important for the state propaganda. The Serbian historian and politician, Stojan Novaković, wrote in 1904 his most famous book entitled The Resurrection of the Serbian State. The book was dedicated to the 1804-1813 Serbian uprising (Novaković, 1904). This was a vivid illustration that, in ideological terms modern Serbian state was to be restored by evoking its pre-Ottoman glory. Nationalism as an awaking was a well known phenomenon (Pavlović 2004: 112). The narrative of an awakened Serbian statehood was mentioned as early as 1804. Accordingly, the country apparently lay dormant for centuries until the valor of the rebels did not awaken her. Serbian philosopher Dimitrije Dositej Obradović who lived in Vienna, when received news about the uprising of 1804, wrote a poem named "Arise Serbia".6 In it he called medieval Serbia "to wake". Moreover, he delineated the potential territories of the future Serbian state.

6 Dimitrije Obradović 1739-1811 representative of the Enlightenment and Rationalism came to Serbia in midst of the 
The Serbian independent feudal areas suffered a crushing blow in 1389, in the Kosovo battle. The lack of unity among the Christians was seen as an essential reason for the Ottoman advance in the XIV. century and for the outcome of the Kosovo battle. Thus, in the new conflict the Balkan people must advance as one. This was stressed already in the mentioned "Načertanije" program of 1844. The importance of the Kosovo cult grew stronger thru XVII and XVIII century as the Serbs took more and more part in the Austro-Ottoman clashes of the XVI and XVII century (Mihaljčić 1989; Čolović: 2016). The national cult was focused on "liberating" all territories that were at least for a short time part of the Serbian feudal state. By doing so, the historical clock would be reversed backward. Thus, the long lines of continuity were linking the XII and the XIX centuries. The centuries of the Ottoman rule on the Balkans and all the changes this rule created were simply to be excluded from the grand narrative.

However, the mediaeval memory did not supersede the reasons of real politics. Namely, the Serbian planning of an advance towards Albania, which was briefly a part of the Serbian emperor's Dušan lands in the XIV century, was founded on the belief that the modern state cannot survive without the sea exit. The "Serbian sea" was to be somewhere near towns of Shkoder and Durres. In sum, the memory of past glory played the role in identity politics as well as in the state imperial plans. ${ }^{7}$

\section{Popular Feelings and the Ottoman Empire}

What did the ordinary people think about the war with the Turkish Empire and returning to the medieval glory? As the literacy rate was as high as $90 \%$ at the turn of the century the common people did not leave many written sources. ${ }^{8}$ It is unquestionable that the collection of the Serbian folk songs, together with the practices of the Serbian Orthodox Church, had a crucial role among the peasants in transmitting the messages about the Serbian medieval statehood and the antiOttoman agenda. Moreover, with the establishment of mandatory elementary education in the 1880s the state acquired new means of influencing its citizens. It is certain that the Kosovo cult was very strong at that time as its importance was definitely on the rise in the XX century (Čolović 2016: 232 ) The state invested much energy in further developing the cult. For example, King Peter I Karadjordjević (1903-1921) revealed a new memorial to Kosovo heroes in southern town of Krusevac in 1904. The first hundred years since the First Serbian Uprising were commemorated. The composition reflected ideas of continuity of the Serbian state and desirable triumphant

First Serbian Uprising, opened Grande Écolein Belgrade. He died in Belgrade in 1811.

7 For more works on medievalism and XX century politics in Serbia see: Marko Šuica, "The image of the battle of Kosovo (1389) today : a historic event, a moral pattern, or the tool of political manipulation" in The uses of the Middle Ages in modern European states : history, nationhood and the search for origins, edited by R.J.W. Evans and Guy P. Marchal,. Houndmills ; New York : Palgrave Macmillan, 2011:152-174.

8 The census of 1890 revealed that the country was populated by $84 \%$ of peasants, while those who could be treated as part of the "intelligentsia " made only $4 \%$ of the population. Čedomir Popov, "Od Berlinskog kongresa do Ujedinjenja 1878-1918" [Since the Congress of Berlin until the Unification 1878-1918], in Istorija srpskog naroda [History of the Serbian People], VI, Belgrade, SKZ: 1994, 28, 31. 
return to Kosovo. Namely, the form of a pyramid included the statue of a blind epic poet. On the top of the structure, the bust of a wounded standard bearer from the Kosovo battle was placed. Above him, a fairy was helping him hold the flag and was simultaneously placing a wrath over his head. "Serbia” was also represented as well, in the form of a woman again stressed the importance of Kosovo as she directing her hand towards this territory (Manojlović-Pintar 2014: 77-78). ${ }^{9}$

A myriad of organizations throughout Serbia worked on disseminating ideas from the national program. The gymnastic society "Dušan the Mighty", which was the colloquial name for the medieval emperor Dušan Nemanjić, was mixing gymnastics and nationalism. The "National Defense" was founded in October of 1908 as an anti-Austrian organization, but worked also on preparing the war with the Ottoman Empire as well. It developed a wide network of collaborators within the Ottoman Empire. This organization encompassed mostly civilians. The more ominous was the "Black Hand" founded in 1911, as a reaction to "too passive" foreign policy of the state, while many members of the officer's core became part of this secret society (MacKenzie 1989: 75). However, it seems that not everyone was obsessed with the ideas of returning to Kosovo. One Serbian deputy said in 1876, in the Parliament, the following words: "If we grab Bosnia, my farm will not get any bigger" (Pavlović 2004: 186).

\section{Military Preparation}

The institution which carried the greatest burden of nation's expectations was the Serbian army. The army crossed a long way from a militia type organization towards the modern mixture of professional and conscript army. In 1883 the army got its professional core. King Milan Obrenović (1868-1889) became personally engaged in military reform, thus created special ties with the troops. Apart from reorganizing the recruit contingents the financial resources became more generous. The new dynasty continued this policy in 1903, but with even greater energy. Thus, in 1906 it was decided to purchase as much as 300 of the most advanced rapid firing artillery pieces from the French producers. Similarly, other technical resources were provided such as machineguns, trucks and airplains (Šarenac 2014;).

The arrival of such powerful resources created impression in the public that something big was done for the national cause, while something even bigger was to be prepared for the future. One of the main persons in the Serbian police, Tasa Milenovic sum up the views of the Belgrade public about the Serbian national program. He wrote, that, regrettably the newly purchased rifles were firstly used during the May coup of 1903 when king and queen were shot dead in Belgrade. He consequently stressed that the newly bought French cannons should not be used in internal Serbian clashes. "Hopefully, these new Schneider guns will first fire at our enemy, there around Skoplje, Priština and Prilep, and, if we are lucky over there, across the Drina River "(Milenković, 1991: 436).

9 Olga Manojlovic Pintar Aheologija secanja. Spomenici i identiteti 1918-1989 [Archeology of Memory. Monuments and Indetities 1918-1989], Čigoja: Belgrade 2014, 77-78. 
At the same time great attention was given to unit cohesion. Serbian Ottoman antagonisms here played also a considerable role. Distinguished fighters from 1805 or 1815 officially became unit patrons and idols of the 1900s soldiers. For example, the XV. regiment celebrated when Stevan Sindjelić died in the 1809 battle. He blow himself up near the gunpowder depot when the Ottoman soldiers managed to penetrate his lines.Events from the medieval times were also memorialized thru modern unit birthdays. The XX. infantry regiment, for example, celebrated the victory of the Serbian knights from 1283 against "Greeks and Tatars". 10

The planning of the Serbian Army Stuff revealed very vividly what was the army's priority. Namely, the generals prepared only one, defensive, plan for the war with Austro-Hungary, while two were ready for the potential clash with Bulgaria. One was defensive and one was offensive. However, there were as much as ten plans for the war with the Ottoman Empire. Moreover, plans against the Ottoman Empire were only offensive ones and implied a joint action of several Balkan armies. By 1912 there were four highly detailed plans for advancing across the Serb-Turkish border (Milić 135, 136).

As the tensions with the Ottoman Empire grew bigger, the atmosphere in the army became packed with various activities. One Serbian officer who came back from his stay in the Russian cadet school noticed the difference in Serbian barracks in comparison to the Russian ones. He said that everyone in Serbia "expected great events" while the soldiers were greeting each other by saying "See you in Kosovo" (Šikoparija 2014: 48).

\section{The Countdown}

By 1912 it became clear that long talks of reforms in the Ottoman Empire did not change for better the position of Christians in the Empire. Moreover, the Italian success against the Ottoman Empire in 1911-1912 showed that some of the major powers could strive towards Ottoman possessions before the Balkan state do the same. The intense pro war campaign in Serbia was let lose in 1912. The Serb-Bulgarian alliance was signed on 13 March 1913. Everything that was previously said or written in a concealed manner was now advocated more openly. Moreover, the public had to be prepared not just for skirmishes at the frontier, but for a full scale offensive warfare. In order to justify this, Serbian intellectuals and politicians relied on various arguments. The endangered position of Serbs in Kosovo and Sandzak Novi Pazar, failed reforms in the Ottoman Empire, but also cases from distant past were all used in order to create bellicose mood and boost morale.

It was necessary to convince the public that all political solutions had been exhausted. In September the Serbian government asked for the creation of an autonomous region for the Serbs living in the Ottoman Empire. It was clear that such requests could hardly be fulfilled by the

10 Држани календар Краљевине Србије за 1905. годину [State calendar of the Kingdom of Serbia for 1905], Belgrade 1905: p. 203. 
Ottoman government. ${ }^{11}$ The Serbian daily Politika attacked the "fairy tale about the reforms in Turkey". "For 34 years we hear about the reforms, since 1878. The reforms have been tried by old Turks, by young Turks, but with fatal results." 12 Thus, the obvious conclusion for the reader was that further appeasement policy could not bring any result. The public was being convinced that, if Serbia does not act swiftly, the Albanian irregulars will exterminate the Serbs, as the Ottoman authorities were too weak to stop this. Turkey was portrayed as "the land of violence", "incapable of governing its various nations and provinces". ${ }^{13}$ The mentions of unpunished murders of eminent local Serbs in the Ottoman Empire presented regular feature in the Serbian press. ${ }^{14}$

The historicity of the Serb-Ottoman conflict had immense role in 1912. Fragments of history were brought together in order to prepare the approaching mobilization of the army. The symbolic meaning of prior wars had to be reinterpreted, so that it could play the role in the present conflict (Schmidt, Schröder: 2003, 9.). Serbian papers evoked the times when the Ottomans established their first foothold in Europe, when fortress at Gallipoli fell in 1354. Its ruins were damaged due to an earthquake. Now the Serbian paper threatened that the new earthquake will push the Ottomans back to Asia. Close collaboration between the Balkan Christians was advocated intensely as this was understood as an important historical lesson. ${ }^{15}$

The Serbian Kingdom thus represented itself not only as protector of the Serbs, but as defender of law and order in general. However, there was a problem how other "civilized" states saw the preparations of Serbs and other Balkan Christians. Great Powers tried to reduce the tensions and avoid war. ${ }^{16}$ This infuriated many in Serbia. It was clear that the war with Turkey signaled the brake with the status quo. Serbia thus insisted that it needs no patronage of Great Powers, but it is fighting for its own place under the Sun. The time seemed to be ripe for a self-confident and the independent action on the Balkans. It this sense, in several texts threats were directed not only towards the Ottoman Empire, but also towards the Austro-Hungary.

"The Serbian people know which paths to go, the people is only restless as it expects the war with its eternal enemy... We are the advocates of the following idea: Balkan to the Balkan people, we are happy that the Balkan nations manage to collaborate, to take by sword what had been taken from them also by the sword from the barbaric Turkish hordes. There will be no peace until the Turks are driven from the Balkans to their Asian home." 17

One of the Serbian officers mentioned in his diary the talk he overheard while traveling in the train compartment. The peasants were disusing the mood in the country. "This is not a joke. So

11 Stanoje Stanojevic, “Autonomija Stare Srbije” [Autonomy of Old Serbia], Politika, 7. 9. 1912.1.

12 "Mačem za slobodu" [With sword for Freedom], Politika, 25. 9. 1912, 1.

13 P. "Iz zemlje nasilja. Kako zivi nas narod u Sandzaku" [From the Land of Violance. How does our People live in Sandžak], Politika, 4. 9. 1912, 1.

14 K. "Ubistva na Kosovu" [Murders at Kosovo], Politika, 10.9. 1912. 1.

15 “Nesib Olsun!”, Politika, 9.9. 1912, 1.

16 "Mucni dani” [Difficult Days],Politika, 12.9. 1912, 1.

17 "Adresa srpske javnosti" [The Letter of the Serbian Public], Politika, 24. 09.1912, 1. 
many people raised their voice, like one man. Everybody thinks alike. That is the big thing! We will expel the Turk from the Balkans" (Šikoparija 2014: 49-50).

When the mobilization was declared in matter of days it became evident that the response was to be a formidable one. Numerous reservists who belonged to the second or even to the third levy came to the meeting places on their own initiative. ${ }^{18}$ The army command had no clue what to do with these extra men. There number was around 20000 . Thus, on the $5^{\text {th }}$ of October 1912 the Minister of War, general Radomir Putnik (1847-1917) issued the order to these men, asking them to return to their homes. Nevertheless, many refused to do so. Consequently several of the Serbian infantry regiments acquired a new epithet, prekobrojni (oversized) (Skoko, Opačić, 1974: 209).

The beginning of the First Balkan War presented a rare opportunity to find out what at least part of the population, the ones who were mobilized, thought about the situation. Namely, aware of the specialty of the moment, many decided to keep precise accounts about their participation "in this historic event". The war diaries became rare opportunity to hear some private thoughts about the 1912 conflict.

One soldier, Stanimir Lalić, wrote: "When the decree of mobilization was declared there was a tremendous joy in our village. Everyone left their field work and there were even musicians who immediately played in the center of the village“. Afterwards, when he crossed the Serb-Turkish border he wrote: "I was joyful, I felt warm in my chest, because we are arriving in the old Dusan's Empire to liberate Serbian slaves from its five century long imprisonment. We are watching the Serbian flat and our eyes were filled with tears." Afterwards, he arrived to place of the Kosovo 1389 battle saying that he was part of the generation which achieved what so many previous Serbs dreamt of: "wholly mission of liberating Kosovo" (Lilić 1998: 15-18).

Another soldier, Viden Tošić, commented that "free brothers go to help the enslaved brothers. He wrote that in 1912, "the Serbian flag was surrounded by Serbian knights" and that the Kumanovo battle meant the "redemption of the day of the Kosovo battle". His fatigue disappeared as he realized that he is in the Dušan's old lands. "The 500 year old wounds have been healed"- he wrote (Lilić 1998: 74-75). Other soldier wrote that he was thrilled to avenge Kosovo, that he was listening about this day since his cradle, his childhood "our imagination was awakened by the folk tradition, by tales heard in school, in the army barracks, it was the Kosovo epic. The message was that Kosovo is still not avenged! We were guided by providence and by the Karadjordje's star!" (Dinic [1922] 2014: 12-13)

\section{Conclusion}

By January 1913 it became obvious that Serbian troops won the great victory against the Ottoman forces. Serbian territory doubled. At every corner popular song, "the Serbian trumpet plays again 
in Kosovo", could be heard (Čolović 2016: 284). The St. Vitus Day, the day of the Kosovo battle of 1389, was usually a day reserved for sadness. Since 1913 it became a day of national pride and joy. The Ottoman Empire ceased to play the role of the Serbian archenemy as was the case throughout the XIX century. Serbian military obsession with Turkey was, in great part, caused by the difficult XIX century struggle for autonomy and finally, state independence. In addition, Serbian maximalist national program left few possibilities for avoiding conflict in with the Ottomans. However, as soon as the fighting ceased, it became apparent that the Serbian elite focused almost exclusively on military matters and that plans for governing such vast new territories were quite confused.

If the Serbian peasants were surprised to see that the "New Territories", how the newly acquired lands were officially called, were much different then they imagined them, the Serbian elite was well aware what will be the situation in Skoplje or Pristina. From the onset, the Serbian project implied idea of national liberation, but also imperialism. Namely, the arrival of the Serbian army was perceived as brutal intrusion by several nations in the region. Some of those where already focused on their own national projects. Leon Trocky wrote already in 1913 that Serbia now controls half a million of Macedonians and half a million of Albanians. "Really a tremendous success! In fact, this one million of hostile people can prove to be fatal for historical existence of Serbia" (Šemjakin 2013: 122). Serbian national program, by stressing the Ottoman question, neglected several others.

\section{Bibliography}

Vuksanović-Anić D. (2014) Stvaranje modern srpske vojske [The Creation of Modenr Serbian Army], Belgrade: SKZ, Vojnoizdavački i novinski centar.

Rajić S. (2014) Aleksandar Obrenović-vladar na prelazu vekova: sukobljeni svetovi [Alexander Obrenović Ruler between the Centures: Conflicting Worlds],Belgrade: SKZ.

Schmidt, B, Schröder, I. (2003) Anthropology of violence and conflict, London, New York: Routledge.

Šikoparija, V. (2014) Secanja srpskog oficira 1900-1918 [Memories of a Serbian Officer 1900-1918] edited by Nikolić K. Belgrade: Zavod za uzdbenike.

Skoko, S, Opačić P. (1974) Vojvoda Stepa Stepanović u ratovima Srbije 1876-1918, [Field Marchal Stepa Stepanovic in Wars of 1876-1918], Belgrade: BIGZ.

Ćorović, V. (1996) Istorija srpskog naroda [History of the Serbian People], III, Belgrade, Banja Luka: Glas srpski; Age d'Homme.

Pavlović, M. (1991) Kralj AleksandarI Karadjordjević u ratu i miru [King Alexander I Karadjordjević, in war and peace], edited by Dimitrijević K, Belgrade: Narodna knjiga.

Novaković, S. (2004), Vaskrs države srpske [The Resurrection of the Serbian state], Novi Sad: Pravoslavna reč.

Stojančević, V. (2004) “Stojan Novaković i njegovo delo Vaskrs državne srpske 1804-1813”, Vaskrs države srpske [The Resurrection of the Serbian state], Novi Sad: Pravoslavna reč: 264-274.

Sugar, F. P. "Eternal and Domestic Roots of Eastern European Nationalism" in Nationalism, edited by Hutchinson, J, Smith, D, A, Oxford, New York: Oxford University Press: 171-177. 
Šemjakin, L. A. (2013) “Leon Trocky’s Writings on Serbia and Serbs during the Balkan Wars (1912-1913), in Balkanski ratovi 1912-1913. Nova viđenja i tumačenja [The Balkan WARS 1912/1913: New Views and Interpretations] edited by Rudić, S, Milkić M, Belgrade: Strategic Research Institute, The Institute of History: 125-129.

Pavlović, K. S. (2004) Istorija Balkana 1804-1945 [History of the Balkans 1804-1945], Belgrade: Clio.

Pintar, M. O. (2014) Arheologija sećanja. Spomenici i identity u Srbiji 1918-1989 [Archeology of Memory. Monuments and Indetities in Serbia 1918-1989], Beograd: Udruženje za društvenu istoriju, Čigoja.

MacKenzie, D. (1989) Apis the congenial conspirator : the life of colonel Dragutin T. Dimitrijević, New York: Columbia University Press.

Šarenac, D. (2014) Top, vojnik i sećanje. Srbija i Prvi svetski rat 1914-2009 [Cannon, soldier and memory. Serbia and the First World War 1914-2009], Belgrade: ISI

Milićević, M. (2002) Reforme vojske Srbije 1897-1900 [Reform of the Serbian Military], Belgrade: Vojnoizdavački zavod.

Tasin dnevnik (1870-1906). Zapisi Tase Milenkovića "prvog srpskog policajca” [Tasa’s Journal (18701906). Notes of Tasa Milenkovic "the first Serbian policeman"], edited by Živojin Aleksić, Vukolić: Belgrade 1991.

Lilić, B. (1998) Memoari srpskih ratnika 1912-1918 [Memories of the Serbian Warriors 1912-1918], Belgrade: ISI.

Dinić, M. D. (2014) Prvi put kroz Albaniju sa šumadijskim albanskim odredom 1912 [First time thru Albania with the Šumadija Detachment in 1912], Kraljevo: Društvo istoricara raškog okruga.

Држани календар Краљевине Србије за 1905. годину [State calendar of the Kingdom of Serbia for 1905], Belgrade 1905: p. 203.

Mihaljčić, R. (1989) The battle of Kosovo in history and popular tradition, Belgrade: Bigz.

Popov, Č. (1994) “Od Berlinskog kongresa do Ujedinjenja 1878-1918” [Since the Congress of Berlin until the Unification 1878-1918], in Istorija srpskog naroda [History of the Serbian People], VI, Belgrade: SKZ: 7-50.

Srbi 1903-1914 istorija ideja [The Serbs 1903-1914 History of Ideas], edited by Ković, M. (2015) Belgrade: Clio.

\section{Press articles:}

Stanoje Stanojevic, “Autonomija Stare Srbije” [Autonomy of Old Serbia], Politika, 7. 9. 1912, 1.

"Mačem za slobodu" [With Sword for Freedom], Politika, 25. 9. 1912, 1.

P. "Iz zemlje nasilja. Kako zivi nas narod u Sandzaku" [From the Land of Violance. How does our People live in Sandžak], Politika, 4. 9. 1912, 1.

K. "Ubistva na Kosovu" [Murders at Kosovo], Politika, 10.9. 1912. 1.

“Nesib Olsun!", Politika, 9.9. 1912, 1.

"Mucni dani" [Difficult Days],Politika, 12.9. 1912, 1.

"Adresa srpske javnosti" [The Letter of the Serbian Public], Politika, 24. 09.1912, 1.

“Odgovor Turskoj” [Response to Turkey], Politika,18.9.1912, 1. 